\title{
Effects of Teachers' Motivation on Students' Learning English in Public Elementary Schools of Pakistan
}

\author{
Syed Hyder Raza Shah \\ Lecturer English at Shaheed Benazir Bhutto University, Sanghar Campus, Pakistan \\ Sehar Naveed \\ BS English Linguistics at Shaheed Benazir Bhutto University, Sanghar Campus, Pakistan
}

\begin{abstract}
The research investigated the effects of teachers' motivation on students' learning English in public elementary schools of Nawabshah, Pakistan. It focused at examining intrinsic and extrinsic motivation of teachers while teaching English language. This research paper took Dornyei's (1994) model in which only Teacher-Specific Motivational component was adopted. The research employed quantitative research method in which questionnaire was distributed among the participants. Data was collected from Pakistani public elementary schools in which randomly 50 male and 50 female teachers participated. The research also collected the data from 230 elementary students. The collected data was analyzed by statistical Package for social sciences (SPSS) software version $20^{\text {th }}$. To accomplish the aim of the study three research objectives and research questions were prepared. A descriptive statistics was performed for question 1 and 3 and independent T-test was done for question 2. The findings indicated that teachers are more extrinsically motivated in public elementary schools. Their extrinsic motivation effects their students' mot ivation too. A comparison of male and female teachers was done via constructing a hypothesis i.e. there is no significant difference between male and female teachers' motivation for teaching English in public elementary schools. The findings rejected the null hypothesis and the independent t-test revealed that there is significance difference between the group and female teachers are more motivated (80.2916) to teach English than male teachers (70.8788). Students believe that teachers brighten their future and help them to be confident at speaking English. The results also indicated that teachers' intrinsic motivation plays more positive role for motivating students to learn English. The study suggested that it is essential to shift teachers' extrinsic motivation into intrinsic motivation for teaching English language.
\end{abstract}

Keywords: Intrinsic and Extrinsic Teachers' Motivation, English Language Teaching, Students' Motivation

DOI: $10.7176 / \mathrm{JEP} / 11-4-05$

Publication date: February $29^{\text {th }} 2020$

\section{Introduction}

Motivation is the most significant and contributing factor for learning and teaching English as a second language (Campbell \& Storch, 2011). Eventually, English is the most emphasized language in Pakistan and still students face hurdles and difficulties in learning English which de-motivate them. Teachers play fundamental role in motivating students to learn English language. Teachers' motivation for teaching English creates an environment of cooperation and support to help students in learning English. Among various motivating factors, this study takes intrinsic and extrinsic motivation of teachers. Teachers are considered as an intrinsically motivated when they perform beyond their job descriptions and teach with self-pleasure. On the other hand, extrinsic motivation for teaching is observed when teachers teach students in order to accomplish assigned task, getting promotion and handsome salary etc.

Dornyei (1994) presented a comprehensive model in which teacher specific motivation is one of the crucial elements. He (1994) presented thirty motivational teaching strategies that can help teachers to increase their students' interest for learning English. Dornyei (2001) is of the view that teachers can change students' interests and help them to solve their problems they face in the way of learning English language. Students from backward areas or from public schools mostly feel anxiety, fear of public speaking and reserved communication with teachers and fellows in English language. According to Shah, et al. (2016) motivational teaching strategies can enhance learners' interest and excitement for learning a second language. It is a challenging task for a teacher to develop interest and enthusiasm for learning English language among students of various backward backgrounds. Dornyei (2001) suggests that teachers should build positive relationship with students in order to remove their hesitation to communicate with them and encourage them to improve their learning without having fear of mistakes and tell them that mistakes are the part of learning. Teachers are mentor, guider and facilitators of the students. They should make learning interesting and enjoyable for students. If teachers are positively motivated and committed with their teaching profession then they can bring revolution in the process of students' learning. The most important factor in learning English is intrinsic motivation. Teachers should be intrinsically motivated and develop intrinsic motivation in students about learning second language.

The trend of learning English language in Pakistan is increasing day by day. The institutions or schools in 
Pakistan demand the learners to learn and communicate in English language (Mehboob, 2002). With the advent of modern and latest technology, the need to learn English is creating the present scenario more complex. The course content, books and other educational materials are only available in English language. The private schools in Pakistan are taking necessary measures to fulfill the demand of learning English language but most of the public schools in Pakistan are still unable to excel with the modern world and latest need of the hour. Keeping this scenario in mind, the need arises to study on the effects of teachers' motivation on students learning English in elementary public schools. This study intends to know the motivating factors of teacher while teaching English and to understand if there is any difference between male and female' motivation for teaching English language. By exploring the effects of teachers' motivation on students' learning, the study will be helpful for teachers of public schools to change their teaching strategies and can help students to learn English effectively without facing difficulties.

\subsection{Research Questions}

Q1. What are the motivating factors of teachers while teaching English in public elementary schools of Nawabshah?

Q2. Is there any difference between male and female teachers' motivation while teaching English in public elementary schools of Nawabshah?

Q.3 To what extent do teachers' motivation affect on students' learning English in public elementary schools of Nawabshah?

\subsection{Hypothesis of the Study}

H1. There is a difference between male and female teachers' motivation for teaching English in public elementary schools of Nawabshah.

H0. There is no significant difference between male and female teachers' motivation for teaching English in public elementary schools of Nawabshah.

\section{Literature Review}

According to Kelly (1974) motivation refers to the force that alters and maintains the intensity, direction and quality of behavior. Dessler (2001) defines motivation as the intensity of an individual's will to engage in certain activities. According to Russell (1971), there are three characteristics that described motivation: it determines the direction for action, it presumed internal force and it energized for that action. Oiolube, (2005), defines motivation is the act that engage an individual to behave in specific manner. Shah et al. (2016) state that motivation for learning English shows learners' intensity and enthusiasm. A successful language teacher is one who motivates learners to learn language.

Intrinsic motivation refers to the individuals' internal will to do something or act in a certain ways. When no one interact an individual to do something but he/she do so with his/her own inner desire is known as intrinsic motivation. According to Shah, et al. (2016) intrinsic motivation gives an individual satisfactory and rewarding experience. Brown (2000, p. 162) says that, those persons are intrinsically motivated who learn for their own self perceived goals and needs. Sansone \& Harackiewicz (2000, p.16) claim that intrinsic motivation helps the students to learn second language for the sake of his internal desire. According to Sansone \& Harackiewicz (2000, p. 273) extrinsic motivation is defined as, a desire to obtain a parents or teacher's approval according to Hall \& Goetz (2013, p. 66) extrinsic motivation is described as the value is not being found in the activity itself, despite in the results of the activity. This type of motivation is based on getting external benefits such as for getting good job, for academic examination, for making foreign friends etc. Shah, et al. (2016) claim that students learn target language for future goals and other practical advantages in extrinsic motivation.

\subsection{Dornyei’s Model (1994)}

Dornyei (1994) presented a three level model which emphasis on educational aspect of motivation. He (1994) within his three levels model (the language level, the learner level and the learning situation level) suggested thirty motivational teaching strategies. His strategies help teachers to increase student's motivation for getting better results. The Dornyei's three levels model and his motivational teaching strategies are discussed below:

\subsubsection{The language level}

This level incorporates basic components of second language motivation which are discussed in the research conducted by Gardener (1985). This level covers the reasons by a learner for choosing a language, either instrumental reason or integrative reason or both reasons. Integrative motivation refers to student's internal desires to learn about target language community or culture. Conversely, instrumental motivation refers to external benefits of learning target language such as academic exams, foreign scholarships, better job opportunities etc.

In this level Dornyei (1994) presented following teaching strategies: 
1. The English as a second language teacher should include cultural and social aspect of second language within the syllabus in order to share positive second language experiences in classroom.

2. Teachers should provide cross cultural integration. They should aware students about differences and similarities of second language.

3. Teachers should provide opportunities and facilities to communicate with native speakers.

4. Teachers should bring students' attention to instrumental motivation.

\subsubsection{The learners' level}

This level indicated the characteristics of the students which helps them in their learning process such as desire for success and self confident. Dornyei (1994) in this level suggested following strategies of teaching:

1. Teachers should increase students' self confidence.

2. Teachers should boost up students self efficacy.

3. Teachers should teach them that mistakes are the part of learning and help them to overcome those mistakes.

4. Teachers should create acceptable and cooperative environment in order to decrease the anxiety of students in second language learning classrooms.

5. Teachers should tell students what they can achieve in second language learning despite what they cannot.

\subsubsection{The learning situation level}

This level indicated situation specific motivation within the setting of language learning classroom. According to Dornyei (1994), this level expresses two different components which are:

$>$ Teacher specific motivation

Teacher specific motivation refers to the motivational effect of teachers' behavior, personality, and teaching practices/methods (Dornyei, 2001).

Dornyei (1994), created six teaching strategies for this aspect of motivation.

1. There are three basic characteristics of a teacher that increase student's performance and learning. First is 'empathy' which means being sensitive to student's perceptions, feelings and requirements. Second is the 'congruence' which means teachers' behavior as being honest and authentic to students and the last one is the 'acceptance' which means positive and non-judgmental, behavior of teacher towards the students and acknowledging all students with both faults and virtues.

2. Teachers should be autonomous to students. They should not give overload or extra burden or pressure to students.

3. Teachers should be facilitator not the authoritative.

4. Teachers should develop extrinsic and intrinsic motivation in the tasks. For that teachers should realize students their mistakes and encourage them to involve in tasks and activities.

5. Teachers should provide students honest feedback about their performance and learning process.

6. Teachers should enhance student's interest in their learning process.

$>$ Course specific motivation

This level of motivation incorporated to the teaching materials, learning tasks, syllabus and teaching method. Dornyei (1994), suggest following teaching strategies for this level of motivation:

1. Course should be design according to the level and needs of the students.

2. Course content should be attractive by including audio and video recording materials.

3. The content of the course should increase students' involvement and interest.

4. The content of the course should be easy and should match with the level of students' abilities.

5. The content of the course should provide satisfaction to the students.

\subsection{Role of Teachers' Motivation on Students' Learning English Language}

Various researchers agreed that one of the factors that influence students' learning English language is the motivation of teachers. Teachers can indulge learners in a long way of learning targeted language. According to Ramage (1990), teachers should attempt to engage the learners in their learning language that can impact students' motivation to get desired results. Dornyei (2001) claims that teachers can effect on students learning target language by implementing different types of teaching strategies. It is crucial to develop friendly and supportive environment of second language learning classroom. Teachers should be mentor, facilitator and guider of students and make the learning process interesting and enjoyable. Teachers should teach them with the use of modern technology and give students the awareness about the culture of the target language. This can help students to learn language effectively and enthusiastically.

Teacher-student relationship is also one of the important factors for the motivation of students to learn a target language. Students face many problems whether personal or mental that can de -motivate them for learning new language. Teachers should develop positive relationship with their students so that they can share their problems with them and teachers can solve their problems. Teachers should highlight to the students the 
benefits of learning language. Intrinsic motivation plays vital role in learning language. Therefore, teachers should develop intrinsic motivation in students for learning language.

\subsection{Previous Studies}

Following are some of the studies' findings that demonstrated what factors influence teachers' motivation which ultimately effect on students learning English.

\subsubsection{Salary and motivation of teachers}

It is the fact that the key element to motivate teachers is salary. It is universal belief that financial satisfaction is an important component of for working or doing any job, no matter what factors of motivation of passion exist in a person for the job. Murnane and Olson (1990) conducted various researches and the findings indicated that salary of teacher is an important factor that determines the time period of the teacher to stay in teaching. The results of the studies also shows that those teachers who paid handsome salary are highly motivated and work for long period in teaching and those teachers who paid less salary stay for a short period of time as well as demotivated in teaching.

\subsubsection{Environment and teachers' motivation}

Working environment has great impact on motivation and self-esteem of teachers and therefore, it affects their progress as well. The main factors include management support, classroom situation, distance, meal, travel and workload effect teachers' motivation. According to Bannell and Akyeampong (2007) the expenses of travel and meal increase teachers' lateness and absenteeism from schools.

\subsubsection{Faculty professional progress and teachers' motivation}

Teachers' professional progress or growth is very important for the enhancement teacher motivation. It has a positive impact on retention and job satisfaction in schools. According to Schmidt (2004) job satisfaction increase with career development in regards to correlation with organizational commitment. Teachers will be more satisfied with their jobs when they take part in professional development trainings.

\subsubsection{Gender and teachers' motivation}

Grubeberg's (1979) research indicates that male and female teachers' motivation is not same. He is of the view that female workers are more concerned with social aspect of job than career aspect of the job as compare to male workers. Male workers are more concerned with career aspect of the job.

\subsubsection{Teaching experience and teachers' motivation}

The research was conducted on elementary head teachers by Ward (1997) on the teaching experience and teachers' motivation. He (1997) is of the view that head and senior teachers had a strong affection of interpersonal relations with teachers as compare to those head teachers who had just five or few years of teaching experience. Another study was conducted by Dinham and Scott (1996) shows that there is no relationship between the length of the teaching experience and job satisfaction. Meanwhile, a significant association occurred between the time period of experience and in job satisfaction.

\subsubsection{Supervision and teachers' motivation}

The supervision of teachers can be both frustrating and rewarding. According to Duke and Stiggins (1990) efficient supervision of teachers can contribute to improve personal growth, professional development and work performance. If teaching supervision is poorly done then the results will be boredom and anxiety. In order to yield a positive outcome teaching supervision must be plan properly.

\section{Research Methodology}

The current study adopted quantitative method to collect data. Quantitative method is very effective to generalize the results to a greater number of the population. According to Dornyei (2007), Quantitative study involves the collection of data processes that results in numerical form which is then analyzed by statistical software such as statistical package for social sciences (SPSS). The population selected for this study was 230 elementary public school students in order to know the effects of teachers motivation on their learning English and 50 elementary public school teachers to know if there is any difference between male and female teachers motivation while teaching English and to know the motivating factors of teachers while teaching English in elementary public schools in Nawabshah.

Two questionnaires were administrated. One questionnaire is adapted for teachers to know the motivating factors of teachers while teaching English in public elementary schools of Nawabshah and to know if there is any difference between male and female teachers' motivation while teaching English in public elementary schools of Nawabshah. The second questionnaire was adapted for students of elementary public schools to know the effects of teachers' motivation on students' learning English in public elementary schools of Nawabshah. The researcher used statistical package for social sciences software (SPSS) $20^{\text {th }}$ version to analyze the data. The SPSS software calculated means, frequency, and standard deviation. Frequency tables were drawn to formulate findings. Fast of all, descriptive statistics is done by SPPS in which descending mean score is generated. Descending mean score helps us to know highest to lowest mean score and it can be assumed that majority of the 
participants consider following factor most and least. Last but not least, an independent $t$-test was also done to know significance difference between male and female teachers' motivation.

\section{Data Analysis and Interpretation}

\subsection{The Analysis of First Research Question}

Q1. What are the motivating factors of teachers while teaching English in public elementary schools of Nawabshah?

Table 4.1: Mean, Minimum and maximum of Motivating Factors for Teachers Teaching English

\begin{tabular}{|c|c|c|c|c|}
\hline \multicolumn{5}{|l|}{ Descriptive Statistics } \\
\hline & $\mathrm{N}$ & Minimum & Maximum & Mean \\
\hline pleasing and helpful atmosphere in the classroom & 50 & 1 & 5 & 3.88 \\
\hline present and manage responsibilities in a motivating way. & 50 & 1 & 5 & 3.82 \\
\hline Earn good salary. & 50 & 1 & 5 & 3.72 \\
\hline Learner's autonomy. & 50 & 2 & 5 & 3.68 \\
\hline Able to work independently and use my own initiative. & 50 & 1 & 5 & 3.66 \\
\hline Manageable work load. & 50 & 1 & 5 & 3.64 \\
\hline Friendly relationship with students. & 50 & 1 & 5 & 3.44 \\
\hline Raise the learners' intrinsic interest in the L2 learning process. & 50 & 1 & 5 & 3.32 \\
\hline Increase students' self-motivating capacity. & 50 & 1 & 5 & 3.30 \\
\hline Build learners' confidence by providing regular encouragement. & 50 & 1 & 5 & 3.16 \\
\hline Offer rewards in a motivational manner. & 50 & 1 & 5 & 3.12 \\
\hline Being an English language teacher is prestigious. & 50 & 1 & 5 & 3.11 \\
\hline Valid N (listwise) & 50 & & & \\
\hline
\end{tabular}

The above descriptive statistic table number 4.1 shows the mean score from top to bottom which clearly explains factors which motivate teachers to teach English as a second language.

This can be categorically viewed that the greatest mean score i.e. 3.88 is about pleasant and atmosphere in classroom. Teachers' motivation is based on the classroom atmosphere which is not only created by teachers but all rest of stake holders. The government elementary school teachers want to present the tasks in motivating way so that the students' motivation can be increased. Meanwhile, lowest mean is 3.12 that show prestigious of English language teachers. The descriptive analysis is further explained in chart one by one below.

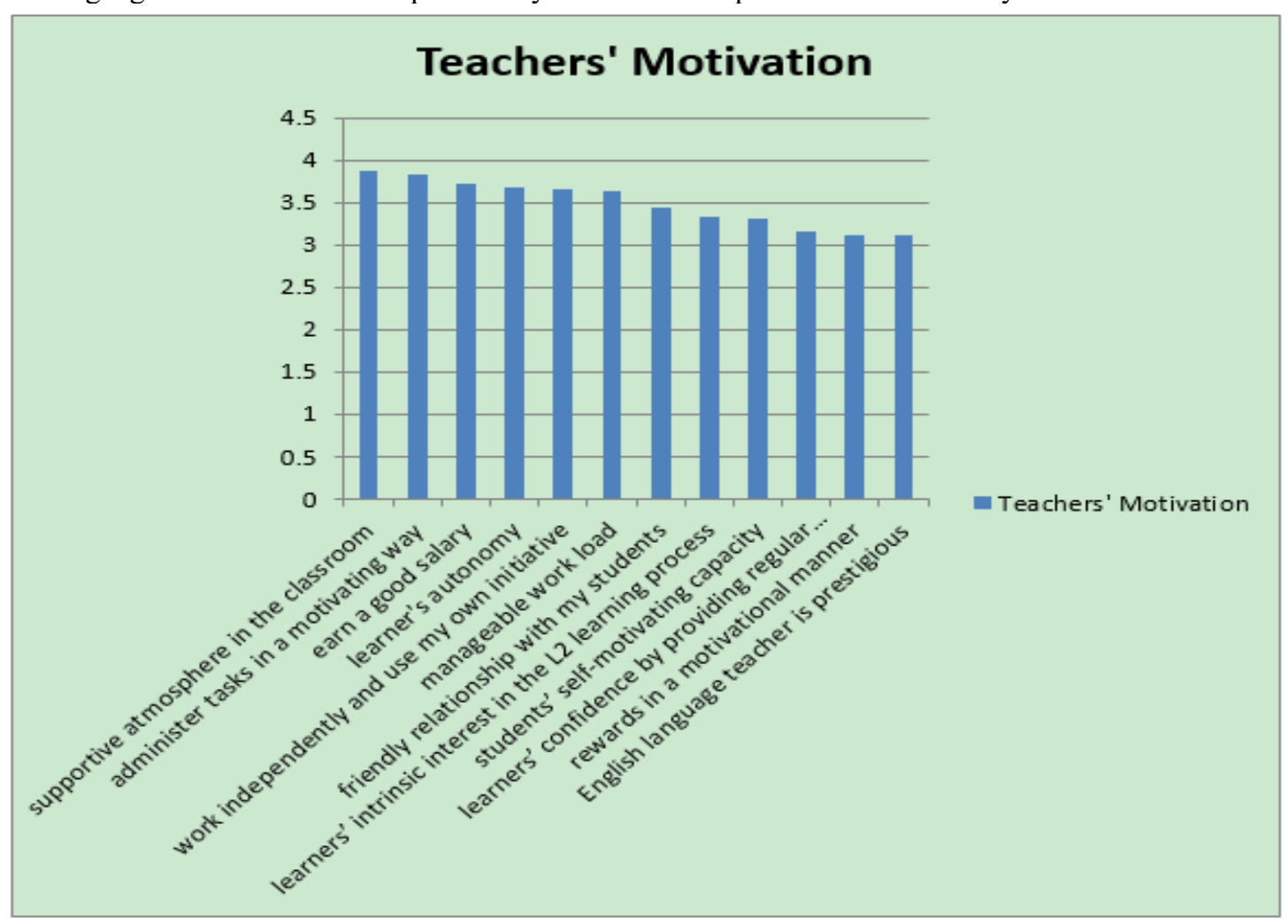

The chart indicates that most of the participants were of the opinion that they are motivated to teach in English because they want to create a pleasant and supportive environment in the classroom to facilitate students 
in learning English. The participants gave it mean 3.88 i.e. highest mean. However, a few participants do not want create pleasant and supportive environment in the classroom for students to facilitate them in learning English. The participants of the study who belong to elementary schools of Nawabshah are motivated to create a pleasant and supportive atmosphere in the classroom because teaching English is not possible without creating speaking atmosphere. Even the motivation of the students also depends on the pleasant and supportive behaviour of teachers. Teachers are highly motivated to teach English because they want to present and administer tasks in motivating way. It is very essential while teaching and it is the sign of a good teacher to bring motivation in teaching and learning process. The participants gave it second highest mean i.e. 3.82. Consequently, the statement reveled that it is essential for teachers to administer task with high carefulness and should take into consideration the interest of learners. It is analyzed that the participants are not only integratively motivated for teaching English but they are also instrumentally motivated and to earn good salary is one of the major motivating factors in teaching foreign language. This statement has got 3.72 mean score. Moreover, almost disagreement of participants may be considered because they give preference to teaching more than salary.

But as the fact, some participants believed that salary makes matter in motivating for teaching English. Whereas, 30 participants do not agree with the statement and they think that teaching is more intrinsic than extrinsic.Teachers motivate students in learning English because they increase students' autonomy in learning English. The participants gave it 3.68 mean. It is true that in public elementary schools teachers can be divided into two different philosophies. One, who believe in traditional teaching system in which a student are supposed to be a good follower and has no right to work according to his or her own capability, Second view is that teachers' role is to facilitate students in studies and consider each individual and creative. This creativity is possible when teachers would promote autonomy among students and that autonomy can also increase students' motivation. The participants were of the view that they are motivated because they are independent and can use their initiatives to help students in their learning process. The participants gave it 3.66 mean.

In previous statement, we discussed the importance of students' autonomy and related it with students' motivation for learning English. Here, once again it is disclosed that both students and teachers should be independent and should use their own initiatives. If teachers and students work independently then they could bring refinement in teaching and learning.The findings indicate that teaching is easy job and teachers can manage work load. 21 participants were of the view that they were motivated to teach English because they can manage work load. The participants gave it 3.64 mean. The participants of the current study have truly expressed that they are having unmanageable work load in their schools. It is also being found in the literature review that in Sindh province the quantity of primary, middle, elementary, and secondary teachers are not sufficient to accommodate teachers in all schools equally. The complaint is because of irregularities in appointment policy and criteria. The participants were of the view that they are motivated to teach in English because they have friendly relationship with their students. The participants gave it 3.44 mean. Some teachers raise learners' intrinsic motivation in second language learning process. The participants gave it 3.32 mean. Intrinsic motivation is very important because when teachers would develop students' self-interest in L2 learning then the students could put extra efforts in learning. As for as current research has indicated that intrinsic motivation refers to learners' inner willingness which is essential for teachers to teach and students to learn as second or foreign language. Teachers increase students'self-motivation capacity to learn English. The participants gave it 3.30 mean.

Each student has his or her particular self-motivation which is also closely attached with intrinsic factors. Raza et al. (2015) say that students' motivation changes time by time and does not stable at a place. Therefore, the more teachers will increase students' self-motivation the more English language learning will be improved. Teachers should understand students' mind and deal them accordingly. Teachers reward students in a motivational way to encourage them in learning English. The participants gave it 3.12 mean. The participants were of the opinion that they teach English because being an English language teacher is prestigious. The participants gave it 3.11 mean.

\subsection{The Analysis of Second Research Question}

Q2. Is there any difference between male and female teachers' motivation while teaching English in public elementary schools of Nawabshah?

Independent sample T-Test (Q2)

Pallent (2005) defined that independent t-test is employed to compare the mean score of two entirely different groups of individuals. It is to do for getting difference. As the current research, intends to know difference between male and female public elementary teachers' motivation for teaching English. For that, there is need to formulate a hypothesis. Therefore, a hypothesis is made which intends to know:

Null hypothesis:

There is no significant difference between male and female teachers' motivation for teaching English in public elementary schools of Nawabshah. 


\subsubsection{Overall teachers' motivation}

Table 4.2: Group Statistics

\begin{tabular}{|l|l|l|l|l|l|}
\hline & V1 & N & Mean & Std. Deviation & Std. Error Mean \\
\hline \multirow{2}{*}{ Teachers Motivation } & Male & 50 & 70.8788 & 8.64711 & .75840 \\
& Female & 50 & 80.2916 & 8.52959 & .85296 \\
\hline
\end{tabular}

According to the table 4.2 the mean of male teachers is 70.8788 and standard deviation is 8.6711 . On the other hand, female teachers' mean score is 80.2916 and standard deviation is 8.529959 . The mean difference between male and female is 9.41283 . So it is assumed from t-test that male elementary public school teachers are less motivated than female elementary school teachers. It is also assumed that there is great.

Table 4.3: Independent Samples Test

\begin{tabular}{|c|c|c|c|c|c|c|c|c|c|c|}
\hline & \multicolumn{2}{|c|}{$\begin{array}{l}\text { Levene's Test } \\
\text { for Equality of } \\
\text { Variances }\end{array}$} & \multicolumn{7}{|c|}{ t-test for Equality of Means } \\
\hline & & \multirow[t]{2}{*}{$\mathrm{F}$} & \multirow[t]{2}{*}{ Sig. } & \multirow[t]{2}{*}{$\mathrm{T}$} & \multirow[t]{2}{*}{ Df } & \multirow[t]{2}{*}{$\begin{array}{l}\text { Sig. } \\
(2- \\
\text { tailed })\end{array}$} & \multirow[t]{2}{*}{$\begin{array}{l}\text { Mean } \\
\text { Difference }\end{array}$} & \multirow[t]{2}{*}{$\begin{array}{l}\text { Std. Error } \\
\text { Difference }\end{array}$} & \multicolumn{2}{|c|}{$\begin{array}{l}95 \% \text { Confidence } \\
\text { Interval of the } \\
\text { Difference }\end{array}$} \\
\hline & & & & & & & & & Lower & Upper \\
\hline $\begin{array}{l}\text { Teachers } \\
\text { motivation }\end{array}$ & $\begin{array}{l}\text { Equal } \\
\text { variances } \\
\text { assumed } \\
\text { Equal } \\
\text { variances } \\
\text { not assumed }\end{array}$ & .008 & .000 & $\begin{array}{l}- \\
.361 \\
- \\
.362\end{array}$ & $\begin{array}{l}228 \\
214.516\end{array}$ & .000 & -9.41283 & $\begin{array}{l}1.14341 \\
1.14136\end{array}$ & $\begin{array}{l}- \\
2.66584 \\
- \\
2.66256\end{array}$ & $\begin{array}{l}1.84018 \\
1.83690\end{array}$ \\
\hline
\end{tabular}

This table 4.3 suggests that $F$ value is .008 and significant value is $(p)$ is .000 which is less than 0.05 . Therefore, the equal variance cannot be assumed. After analyzing the LEVEN'S Test for equality variance, it is clearly shown in the table that the value is .362 and significant value (p) is .000 that is also less than 00.5.

Therefore, the null hypothesis can be rejected and alternative hypothesis is accepted. The result of independent t-test suggests there is significant difference between male and female teachers' motivation for teaching English in elementary public schools of Nawabshah.

\subsection{The Analysis of Third Research Question}

Q3.To what extent does teachers' motivation affect students' learning English in public elementary schools of Nawabshah?

\begin{tabular}{|c|c|c|c|c|}
\hline \multicolumn{5}{|l|}{ Table. 4.4: Descriptive Statistics } \\
\hline & $\mathrm{N}$ & Minim & Maxim & Mean \\
\hline 6. The teacher promotes cooperation among the learners. & 230 & 1 & 5 & 3.72 \\
\hline $\begin{array}{l}\text { 9. The teacher raises the learners' intrinsic interest in the L2 learning } \\
\text { process. }\end{array}$ & 230 & 1 & 5 & 3.70 \\
\hline $\begin{array}{l}\text { 1. The teacher increases the students' expectancy of success in } \\
\text { particular tasks and in learning in general }\end{array}$ & 230 & 1 & 5 & 3.65 \\
\hline $\begin{array}{l}\text { 8. The teacher promotes the students' awareness of the instrumental } \\
\text { values associated with the knowledge of an L2. }\end{array}$ & 230 & 1 & 5 & 3.64 \\
\hline $\begin{array}{l}\text { 3. The teacher uses grades in a motivating manner, reducing as much } \\
\text { as possible their demotivating impact }\end{array}$ & 230 & 1 & 5 & 3.33 \\
\hline 4. The teacher provides students with positive information feedback. & 230 & 1 & 5 & 2.87 \\
\hline $\begin{array}{l}\text { 10. The teacher develops a collaborative relationship with the students' } \\
\text { parents. }\end{array}$ & 230 & 1 & 5 & 2.59 \\
\hline Valid N (listwise) & 230 & & & \\
\hline
\end{tabular}

The above table 4.4 indicated the descriptive statistics of question number three. This question intends to get know about the effectiveness of students' motivation from teachers' perspective. This is very essential after teachers to know about students' affecting factors and their motivation level. The questionnaire was filled by 230 elementary students of government schools. The result from top to bottom in this descriptive table shows that teachers promotes co-operation among students and this has highest mean score i.e. 3.72. Whereas, lowest mean is 2.59 which determines that teachers develop collaboration with students' parents. 


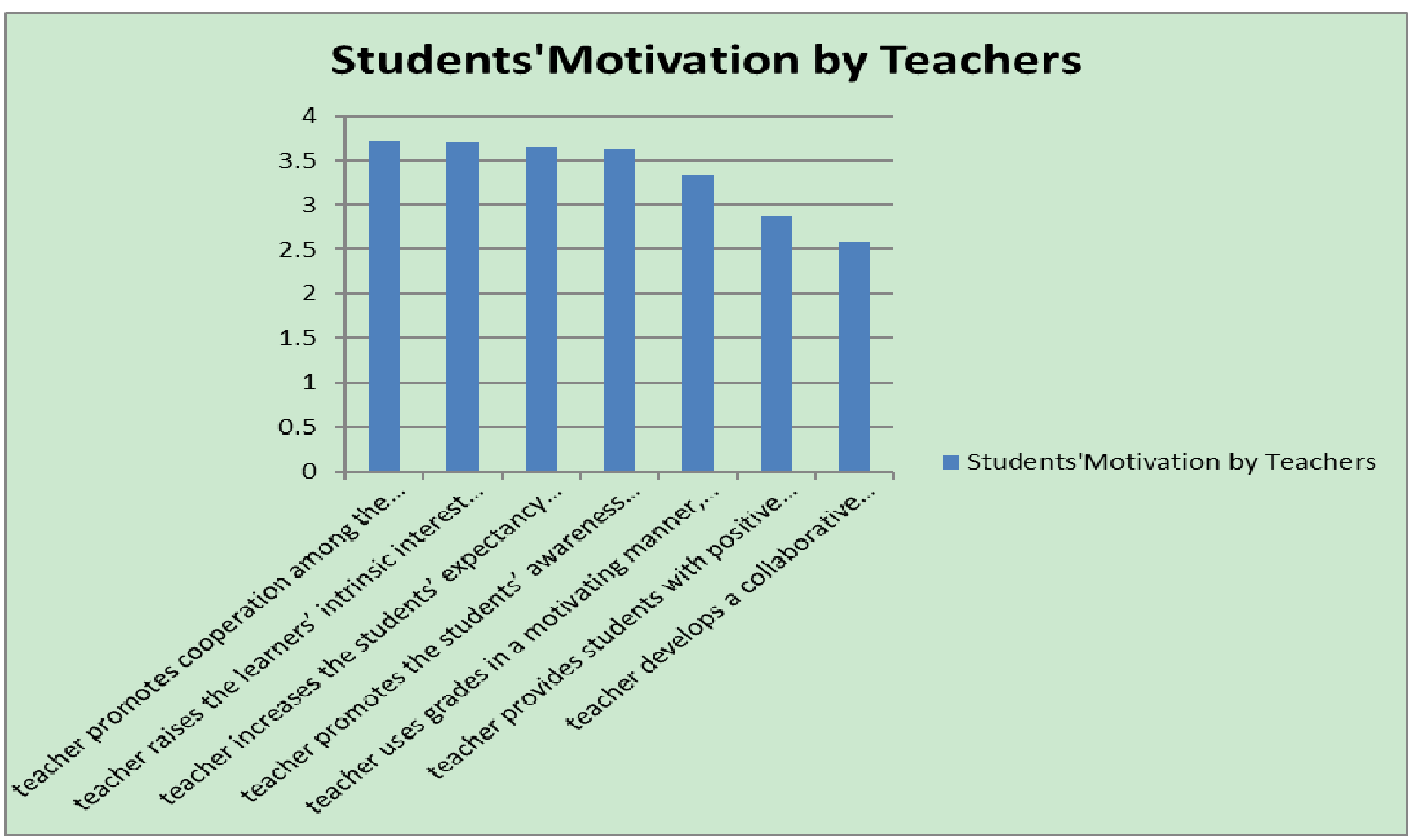

The finding of the chart shows that participants believe that teachers promote cooperation among the students for learning English as second language. Some participants were of the view that teachers do not promote cooperative environment among students. The participants gave it highest mean 3.72. Coincidently, the highest mean in question number one of the study which was about teachers' motivating factors went for classroom pleasant and supportive atmosphere. It means that teachers as well as students think same that classroom atmosphere and cooperation among learners are highest motivating factors for improving students' motivation to learn a second language. The participants believe that teachers raise the learners' intrinsic interest in L2 learning Process. However, some participants do not agreed with the statement. The participants gave it second highest mean 3.70. Surprisingly, the same statement was in previous questionnaire in which 3.2 mean score was recorded and the same percentage and almost same mean score is too. This indicates the importance of intrinsic motivation for learning a second language.The participants of the research believe that teachers increase the students' expectancy of success in learning English. A few participants were of the view that teachers do not increase the students' expectancy of success in learning English. The participants gave it mean 3.65. Students believe that teachers promote the students awareness of the instrumental values associated with the knowledge of L2.

The participants also believe that teacher uses grades in a motivating manner, reducing as much as possible their de-motivating impact. Some participants were of the view that teachers do not teacher uses grades in a motivating manner, reducing as much as possible their de-motivating impact. The participants gave it mean 3.33. The participants stated that teachers provide students with positive information feedback. Since, more than agreed numbers do not agreed with the statement. The participants gave it mean 2.87 . The participants believe that teachers develop a collaborative relationship with the students' parents. Participants were of the view that teachers do not develop a collaborative relationship with the students' parents. The participants gave it mean 2.59 . Only 12 participants do not answer this question.

\section{Conclusion and Recommendations}

The research analyses the results and interprets its major findings. The present research is based on the three main objectives. The first and foremost objective was to know the teachers' motivating factors while teaching English at government elementary schools of Nawabshah. The results revealed that pleasant and supportive atmosphere of classroom, administration of task in motivating way, salary, work load and etc are extrinsic and intrinsic teaching motivating factors while teachings English. The second objective of the research is to find out difference if any between the male and female teachers' motivation for teaching English. Interestingly, the results showed that there is difference between male and female teachers' motivation and male teachers are less motivated than female teachers. Last but not least, students' motivation is affected by teachers' motivation and teachers' increases cooperation among students, give value to intrinsic as well as extrinsic motivation of students.

The research recommends following points based on the findings. 
1. The research should also conduct on qualitative method.

2. There should be more intrinsic motivation for teaching English.

3. Teachers should have positive contact with students' parents at elementary level.

4. Teachers should increase students' intrinsic as well as extrinsic motivation for learning English.

5. There should be more rewarding and less punishment system at elementary level.

6. Teachers should provide feedback of each assessment to students in motivating manner.

7. No personal target or no personal criticism should be in classroom by teachers.

8. Collaborative learning and teaching is more important than lecturing method in elementary level.

9. Classroom atmosphere should be pleasant and supportive.

10. Friendly relationship should be promoted between teacher and student.

11. Teachers' salary should be according to their prestigious.

12. Work load should be manageable.

\section{Reference}

Akyeampong, A, and Bennell, P.S. (2007). Teacher Motivation in Sbu- Saharan and African and South- Asia. London: DFID.

Brown, H.D. (2000) Principles of Language Learning and Teaching. 4th ed. New York: Pearson Education

Campbell, E., \& Storch, N. (2011) The Changing Face of Motivation. Australian Review of Applied Linguistics, Vol.34/2, 166-192.

Dessler, G. (2001). Management: Leading People And Organizations In The 21st Century. Harlow: Prentice Hall.

Dinham, s. \& Scott, C. (1996). The Teacher 2000 Project: A Study of Teacher Satisfaction, Motivation and Health. Sydney: University of Western Sydney, Nepean.

Dörnyei, Z. (1994). Motivation and motivating in the foreign language classroom ${ }^{\mathrm{ee}}$. Modern Language Journal, 78, pp. 273-284.

Dörnyei, Z. (2001), Teaching and Researching Motivation, Longman, Harlow.

Dörnyei, Z. (2007), Research Methods in Applied Linguistics: Quantitative, Qualitative and Mixed Methodologies, Oxford University Press, Oxford pp. 15-35.

Duke, D. \& Stiggins, R. (1990) Beyond Minimum Competence: evaluation for professional development. The New Handbook of Teacher Education. Newbury Park: Sage Publications.

Gardner, R. C. (1985). Social Psychology And Second Language Learning: The Role of Attitudes and Motivation. London: Edward Arnold.

Grunenberg, E. (1979). Understanding job satisfaction in Newyork: John Wiley Hall, N. C., \& Goetz, T. (Eds.). (2013). Emotion, motivation, and self-regulation: A handbook for teachers. Bingley, UK: Emerald.

Herzberg, F., Mausner, B. \& Snyderman, B.B. (1959). The Motivation To Work (2nd Edition). New York: John Wiley And Sons.

Kelly, J. (1974). Organizational Behaviour. Homewood: Richard D. Irwin.

Murnane, R.J., \& Olsen, R.J. (1990). The effects of salaries and opportunity coast on length of stay in teaching: Evidence from North Carolina. Journal of Human Resourses, 25, 106-124.

Mehboob, A. (2002) No English, No Future: Language Policy in Pakistan. In S. Obeng \& Hartford (eds.) Political Independence With Linguistic Servitude: The politics about languages in the developing world. New York: NOVA Science.

Oiolube.P (2005), Job Satisfaction and Motivation for School Effectiveness: An Assessment University Of Helsinki Finland.

Pallant, J. (2005) SPSS Survival Manual: A step by step guide to data analysis using SPSS version 12 , Maidenhead : Open University Press.

Ramage, K. (1990). Motivational factors and persistence in foreign language study. Language Learning, 40, 189-219.

Raza, S. H., Pathan, H., Khatoon, S., \& Bukhari, S. W. (2015). A Longitudinal Study of Motivation as a Dynamic Process in Learning English as Second Language (ESL) among Undergraduate Students of Engineering University at Jamshoro. 7

Russel, L. (1971). Motivation: Dubuque, IA:WM.C. Brown Company.

Sansone, C. And Harackiewicz, J.M. (2000). Intrinsic And Extrinsic Motivation: The Search For Optimal Motivation And Performance. San Diego: Academic Press.

Schmidt, Steven W., (2004). The Relationship Between Satisfaction with On-The-Job Training and Overall Job Satisfaction. Unpublished doctoral dissertation. University of Wisconsin, Milwaukee.

Shah, S. H. R., Memon, D. S., \& Shah, W. A. (2016). Motivational Teaching Strategies for English Language Learning. 2(2), 21.

Ward, E.A. (1997). Multidimensionality of Achievement Motivation among Employed Adults. The Journal of Social Psychology, 137(4), 542-544. 